20

\title{
Analysis of SAVI Learning Model with the Task of Observation of Video on Science Learning in Producing Analytical Thinking and Critical Thinking Abilities
}

\author{
Deni Nasir Ahmad $1^{*}$ \\ ${ }^{1}$ Pendidikan Matematika, Fakultas Matematika dan IPA, Universitas Indraprasta PGRI, Indonesia \\ DOI: $10.29303 /$ jppipa.v7i1.543
}

\section{Article Info}

Received: November 29th, 2020

Revised: January 28th, 2021

Accepted: January 31th, 2021

\begin{abstract}
The aim of the researcher is to find out how much change in learning outcomes (analytical thinking and critical thinking skills) by using the SAVI learning model with the assignment learning method using the learning media of science learning video recordings that have been prepared by the researcher. The method used in this research is quantitative research with quasi-experimental research methods in managing research data using the t-test and to see if there is a linear relationship, the researcher tests the hypothetical pre-test before testing the hypothesis or t-test. The results of the study were that there was no indirect relationship between the SAVI learning model and the science learning video observation task on analytical thinking skills and there was a relationship between the SAVI learning model and the science learning video observation task on critical thinking skills. It can be concluded that the Somatic, Audiotorist, Visual and Intelligence (SAVI) learning model can improve and help develop critical thinking skills while improving and developing analytical thinking skills requires learning stages that emphasize an initial or previous learning experience in learning when using the model SAVI learning.
\end{abstract}

Keywords: SAVI; Science Learning; Video; Critical Thinking; Analytical Thinking

Citation: Ahmad, D. (2021). Analysis of SAVI Learning Model with the Task of Observation of Video on Science Learning in Producing Analytical Thinking and Critical Thinking Abilities. Jurnal Penelitian Pendidikan IPA, 7(1), 121-128. doi:https://doi.org/10.29303/ippipa.v7i1.543

\section{Introduction}

Education is a process to influence students so that they can adapt as best as possible to their environment and thus cause changes in themselves that allow them to function strongly in people's lives (Sutarna, 2018). One of the most important elements needed for the survival and development of a nation is education and human resources that are superior, quality, and have the courage to compete are the results of a good education (Datingawati, et al., 2020). Therefore, education is needed by humans to produce human resources where these human resources are produced from a process that can influence students to be able to adapt or be sensitive to changes in their environment or technological developments so that students can participate in providing roles and benefits to the environment.

The role of education is to encourage every human being to obtain their rights in receiving educational services. Therefore, education encourages humans to carry out a series of educational processes through learning activities to produce changes in humans into quality human resources. Learning outcomes are usually used as a measure to find out how far someone has mastered the material that has been taught (Dewantara, et al, 2013). The learning process that can improve the abilities of students is the translation of education based on law no. 20 of 2003, namely education is a deliberate and planned conscious effort to create an atmosphere of learning and the learning process so that students actively develop their potential to have religious-spiritual strength, self-control, personality, 
noble moral intelligence, and skills needed by themselves, the community, nation, and state. From these laws, it is clear that the learning process is a planned process by creating an atmosphere of learning and an active learning process.

The learning process that creates an atmosphere of learning and an active learning process in learning methods and models has been widely used. Based on the results of research by Hasnah and Dewi (2018), it is explained that the learner is not ready, who are still not familiar with using the SAVI learning approach where students are still influenced by individual learning habits or competing personally. Furthermore, based on the research results of Wijayanti, et al (2013) that SAVI is also able to overcome different types of student learning either somatically, auditory, visually, and intellectually. Therefore, the researcher aimss to find out how much change in learning outcomes i.e ability to analyze and think critically by using the SAVI learning model with the assignment learning method using the learning media of science learning video recordings that the researcher has prepared. Learning with the SAVI model emphasizes that learning must take advantage of all the sensory devices that students have, namely doing movement (somatic), listening (auditory), observing (visual), and thinking (intellectual) (Sutarna, 2018). SAVI learning adheres to a modern cognitive science school which states that the best learning involves emotions, the whole body, all senses, and all personal depth and breadth, respecting the learning styles of other individuals by realizing that people learn in different ways (Armawati, 2015). The acronym of the SAVI model means somatic (S) which means body movement, auditory (A) which means that learning must speak and hear, visual $(\mathrm{V})$ which means learning by observing and describing, and intellectual (I) learning by solving problems (Wijayanti, Prayitno, Marjono; 2013).

The advantage of the SAVI learning model is that SAVI learning is a learning model that involves students taking part in the learning process actively through a problem-solving learning process (Septian, et al., 2020). Then the advantages of the SAVI learning model from the research results of Yuliatun et al. (2018) show that physics learning (learning remediation) using the SAVI learning model can improve the cognitive abilities of students of class X MIPA 1 Senior High School 5 in Surakarta. Involving students directly through learning media can be done through experimental activities in the laboratory, displaying videos with sound related to teaching materials to foster students' curiosity about an event, it can also be done by demonstrating a situation related to the material and asking students to express their opinions (Rahmayanti, et al, 2016). Furthermore, based on the results of Yuliastiono's research, Sedyawati (2013) explains that the learning outcomes of the SAVI learning model with the help of CD media, namely (1) students feel happy and motivated to take lessons, when learning applies the SAVI learning model with interactive CD media (2) students are easy understand the hydrocarbon material presented through the SAVI learning model with interactive CD media (3) students feel curious and motivated to make questions or ask questions when they feel unclear, (4) students are motivated to actively respond to existing problems, (5) students find it easier to remember the hydrocarbon material that has been delivered with the SAVI learning model with interactive CD media, (6) students feel the need for the SAVI learning model with interactive CD media to be applied to other subject matter, (7) the application of the SAVI learning model with interactive CD media makes students find it easier to complete problems, (8) the application of the SAVI learning model with interactive CD media makes students excited to learn, (9) students feel interested in deepening chemistry, (10) the SAVI learning model with interactive CD media makes students' attention focused while taking lessons.

Furthermore, the conclusions of Ginting and Amir's research (2012) in general, the Somatic, Auditory, Visual and Intellectual (SAVI) learning model can improve the quality of learning Physical Chemistry Subject II in the Chemistry Education Study Program for the 2011/2012 academic year. Student learning outcomes generally increase despite fluctuations due to differences in the difficulty level of the material being taught. Student activeness increased from 70 to $90 \%$ in learning using the SAVI model assisted by computerbased media. It can be concluded from the 2 results of the study that the SAVI learning model with the help of learning media can help in increasing learning achievement. According to Ariyani, et al (2018) in the results of research that have been carried out, namely explaining that learning media based on an example of a character image (Photonovela learning media) will produce cognitive and character abilities, based on examples shown in learning activities. However, researchers still want to explore and try to find out the increase in learning outcomes or learning achievement with the SAVI learning model by testing the expected abilities, namely the ability to analyze and think critically as feedback in providing learning with learning media so that research achievement is as expected. Where the ability to think analytically according to Ilma, et al. (2017) is analytical thinking which includes cognitive processes, including (1) differentiating, involving the process of sorting out the relevant and important parts of a structure. (2) organizing involves the process of identifying the elements of communication or situations and the process of recognizing how these elements form a coherent 
structure. (3) give attributing, involves a deconstruction process in which students determine the purpose of the elements or parts that make up a structure. Furthermore, according to Parta (2016) is thinking which is included in the type of analytical thinking which includes the ability to analyze, compare, and evaluate. From the two results, it is explained that the ability to analyze is the ability to test a truth through a series of analytical activities including cognitive processes such as distinguishing, organizing, and deconstructing a truth to form a coherence structure or in other words analyzing, comparing and evaluating an answer to the truth.

Critical thinking skills are intended as rational and reflective thinking and are focused on making decisions to believe and do something or not (Sumaryanta, 2018). According to Ennis (Fatmawati, 2014) indicators of critical thinking derived from critical activities, namely: (1) able to formulate issues; (2) able to reveal the facts needed to solve a problem; (3) able to choose logical, relevant, and accurate arguments; (4) able to detect bias based on different viewpoints; and (5) able to determine the consequences of a statement taken as a decision. Furthermore, according to Silvester Mas (2012), the ability to think critically must meet several aspects that must be met in learning activities including (1) the ability to understand the definition and clarification of problems, (2) the ability to assess and process information, and (3) the ability to solve problems/create the conclusion. From this opinion, the conclusion is that the ability to think critically is the ability to solve problems in the form of the ability to understand and formulate a problem, the ability to process information by comparing existing facts by detecting a problem by choosing logical, relevant and accurate arguments to obtain conclusions on the findings or answers to these problems.

\section{Method}

This research is quantitative research with a quasi-experimental research method where the researcher carries out a series of activities to explore the expected abilities in learning activities in the form of the ability to analyze and think critically. The sample in this study were biology education students in semester 3 of the 2020/2021 academic year in an introductory education course. In obtaining research data sources the researcher conducted tests, namely testing with several science learning videos on differences in classroom situations and the character of the teachers who taught. To calculate the results obtained from the data, the researcher conducted the t-test in providing the final answer in the research test.
Indicators in making questions on the task of observing 4 science learning videos at the junior high school level in various schools, namely: 1 . Use of the media used. 2 . Teacher communication with students in learning. 3. The way the teacher evaluates the learning that has been done as feedback in learning. In obtaining the final result of the task of observing the researcher gives a score on the final result, which is a score of 10 to 100.

In testing the ability to think, analyze and think critically, the researcher makes an assessment score as follows:

Table 1. Test Score of Critical Thinking ability Based on Test Indicator

\begin{tabular}{lll}
\hline No & Test Indicator & Score \\
\hline 1 & $\begin{array}{l}\text { Ability to understand and formulate a } \\
\text { problem }\end{array}$ & 15.0 \\
2 & $\begin{array}{l}\text { Ability to process information by } \\
\text { comparing facts }\end{array}$ & 20.0 \\
3 & $\begin{array}{l}\text { Detect a problem by choosing logical, } \\
\text { relevant, and accurate arguments }\end{array}$ & 30.0 \\
4 & $\begin{array}{l}\text { Make conclusions on findings or answers } \\
\text { to problems that have been resolved or } \\
\text { found }\end{array}$ & 35.0 \\
Total score & 100.0 \\
\hline
\end{tabular}

Table 2. Test Score of Analytical Thinking Ability Based on Test Indicator

\begin{tabular}{lll}
\hline No & Test Indicator & Score \\
\hline 1 & $\begin{array}{l}\text { Menganalisis meliputi mengorganisasikan } \\
\text { atas permasalah yang akan di selesaikan }\end{array}$ & 20.0 \\
2 & $\begin{array}{l}\text { Membandingkan meliputi membedakan, } \\
\text { mengkelompokkan, mengklasifikasikan }\end{array}$ & 35.0 \\
3 & $\begin{array}{l}\text { Mengevaluasi meliputi adanya kelemahan } \\
\text { dan kelebihan atas suatu jawaban sehingga }\end{array}$ & 45.0 \\
& $\begin{array}{l}\text { menjadi soluasi luaran yang dihasilkan. } \\
\text { Total score }\end{array}$ & 100.0 \\
\hline
\end{tabular}

\section{Results and Discussion}

\section{A. Descriptive Data Analysis Test}

Results of Analysis of Test Data Description of Analytical Thinking Ability

Table 3. Results of Analytical Thinking Ability Test Scores

\begin{tabular}{llll}
\hline No. & Score & Total & Percentage \\
\hline 1 & 70.0 & 2.0 & 7.10 \\
2 & 75.0 & 7.0 & 25.0 \\
3 & 80.0 & 13.0 & 46.4 \\
4 & 85.0 & 6.0 & 21.4 \\
Total & & 28.0 & 100.0 \\
\hline
\end{tabular}

From the table, it can be seen that the analytical thinking ability scores of students with the SAVI learning model (somatic, audiotory, visual, and intelligence) with the science learning video learning 
media show that the score of 80.0 was obtained more by students, namely 13 people or 46.4 percent with the highest score of 85.0, namely 6 students or 21.4 percent, it is possible that the students' analytical thinking ability is at the good ability stage in analyzing the problems given, namely in the form of questions that must be answered by students. So that a histogram graph can be made as follows:

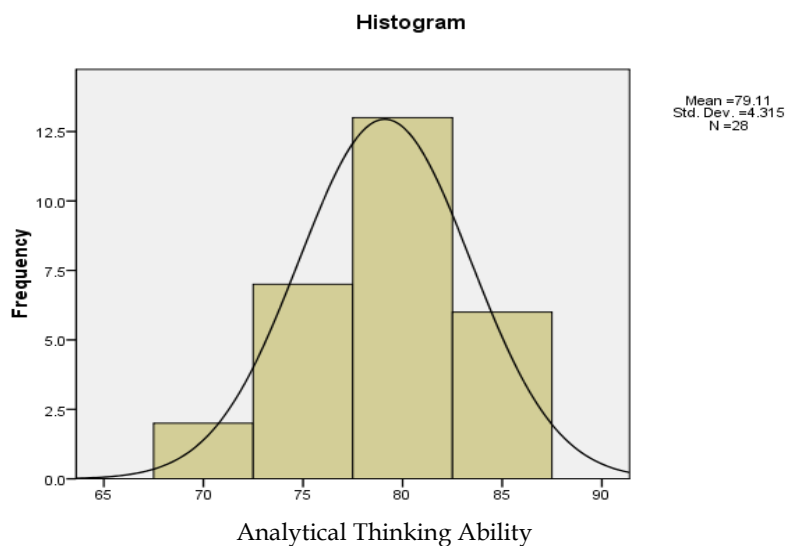

Figure 1. Histogram of Analytical Thinking Ability

From this graph, it can be seen that the highest score from the graph is located between the scores of 78 to 84 to the right, indicating that the students' analytical thinking skills have a positive or rightward movement. The histogram graph illustrates that students' analytical thinking skills are at an intermediate or good stage.

Results of Analysis of Test Data Description of Critical Thinking Ability.

Table 4. Results of the Critical Thinking Ability Test Score

\begin{tabular}{llll}
\hline No & Score & Number of Students & Percentage \\
\hline 1 & 75.0 & 8 & 28.6 \\
2 & 80.0 & 17 & 60.7 \\
3 & 85.0 & 3 & 10.7 \\
& Total & 28 & 100.0 \\
\hline
\end{tabular}

From the table, it can be seen that the scores of students' critical thinking skills with the SAVI learning model (somatic, audiotory, visual, and intelligence) with the science learning video learning media show that the score of 80 is more obtained by students, namely 17 people or 60.7 percent with the highest score 85.0, namely 3 students or 10.7 percent, it is possible that the students' critical thinking skills are at the good ability stage in criticizing the problems given, namely in the form of questions that must be answered by students, so that a histogram graph can be made as follows:

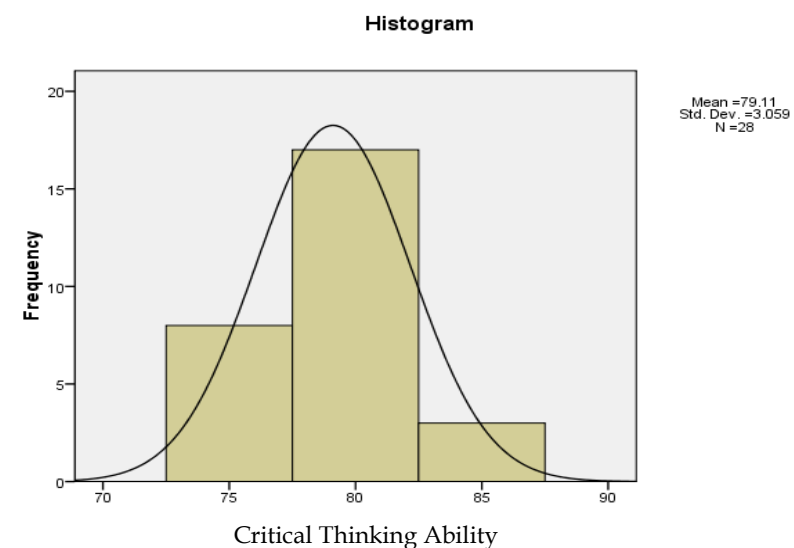

Figure 2. The Histogram of Critical Thinking Ability

From this graph, it can be seen that the highest score from the graph is located between the scores of 78 to 84 to the right, indicating that students' critical thinking skills experience a movement in a positive direction or towards a rightward movement. The histogram graph illustrates that students' critical thinking skills are at an intermediate or good stage.

Results of Analysis of Test Data Description of SAVI Learning Model (somatic, audiotory, visual, and intelligence)

Table 5. The Results of the Test Score of the SAVI Learning Model with the Science Learning Video Media

\begin{tabular}{llll}
\hline No. & Score & Number of Students & Percentage \\
\hline 1 & 74.0 & 1 & 3.6 \\
2 & 75.0 & 1 & 3.6 \\
3 & 76.0 & 2 & 7.1 \\
4 & 78.0 & 5 & 17.9 \\
5 & 79.0 & 8 & 28.6 \\
6 & 80.0 & 5 & 17.9 \\
7 & 81.0 & 5 & 17.9 \\
8 & 83.0 & 1 & 3.6 \\
& Total & 28 & 100.0 \\
\hline
\end{tabular}

From the table, it can be seen that the score of the test results with the SAVI learning model (somatic, audiotory, visual and intelligence) with the science learning video learning media shows that the score of 79.0 was obtained more by students, namely 8 people or 28.6 percent with the highest score of 83.0 namely 1 student or 3.6 percent, it can be seen from the descriptive data that the questions given were in the form of giving the SAVI learning model assignment with science learning videos having an impact on the expected results because the distribution of student scores was quite good. So that a histogram graph can be made as follows: 


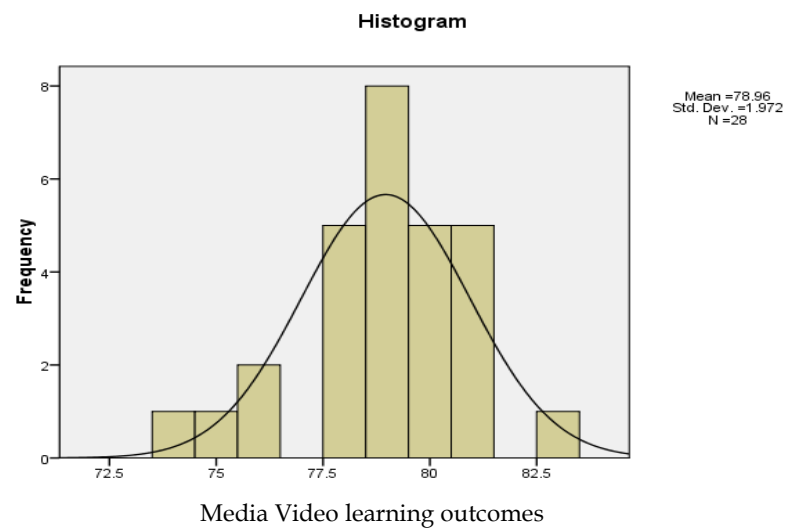

Figure 3. Histogram of the Results of the SAVI

Learning Model Task with the Science Learning Video Media
From the graph, it can be seen that the highest score from the graph lies between the scores of 77.5 to 79 to the right, indicating that the results of the task of the SAVI learning model with the Science Learning Video Media are experiencing a positive movement or towards a rightward movement. From the histogram graph illustrates that the results of the assignments from the SAVI learning model questions with the Science Learning Video Media are at an intermediate or good stage.

\section{B. Linearity Test Analysis}

Analysis of Linearity Test Using the SAVI Learning Model with the Task of Observation of Science Teaching Videos on Analytical Thinking Ability

Table 6. Results of the Linearity Test Score Using the SAVI Learning Model with the Task of Observation of Science Learning Videos on Analytical Thinking Ability

\begin{tabular}{|c|c|c|c|c|c|c|}
\hline & & & $\begin{array}{l}\text { Sum of } \\
\text { Squares }\end{array}$ & $\mathrm{df}$ & $\mathrm{F}$ & Sig. \\
\hline Video Media Learning & Between Groups & (Combined) & 18.959 & 3 & 1.763 & 0.181 \\
\hline Outcomes * Analytical & & Linearity & 9.501 & 1 & 2.651 & 0.117 \\
\hline \multirow[t]{3}{*}{ Thinking Ability } & & $\begin{array}{l}\text { Deviation from } \\
\text { Linearity }\end{array}$ & 9.458 & 2 & 1.320 & 0.286 \\
\hline & Within Groups & & 86.005 & 24 & & \\
\hline & Total & & 104.964 & 27 & & \\
\hline
\end{tabular}

The table explains that there is a relationship between the use of the Savi Learning Model and the Science Learning Video Observation Task on Analytical Thinking Ability where the significant level is $5 \%$ or greater than 0.05 , namely $0.286>0.05$. The analysis test Fcount $<$ Ftable shows that $1.32<3.40$ then it is linear. The results of the analysis test indicate that the use of the
SAVI Learning Model and the Science Learning Video Observation Task on Analytical Thinking Ability has linearity or relationship between the dependent variable and the independent variable (independent).

Analysis of Linearity Test Using the SAVI Learning Model with the Task of Observation of Science Learning Videos on Critical Thinking Ability.

Table 7. Results of the Linearity Test Score Using the SAVI Learning Model with the Task of Observation of Science Learning Videos on Critical Thinking Ability

\begin{tabular}{|c|c|c|c|c|c|c|}
\hline & & & Sum of Squares & $\mathrm{df}$ & $\mathrm{F}$ & Sig. \\
\hline Learning Outcomes of & Between Groups & (Combined) & 30.187 & 2 & 5.046 & 0.014 \\
\hline Video Media * Critical & & Linearity & 27.996 & 1 & 9.360 & 0.005 \\
\hline \multirow[t]{3}{*}{ Thinking Ability } & & $\begin{array}{l}\text { Deviation } \\
\text { from Linearity }\end{array}$ & 2.191 & 1 & .733 & 0.400 \\
\hline & Within Groups & & 74.777 & 25 & & \\
\hline & Total & & 104.964 & 27 & & \\
\hline
\end{tabular}

From the table, it explains that there is a correlation between the use of the Savi Learning Model and the Science Learning Video Observation Task on the Critical Thinking Ability where the significant level is $5 \%$ or greater than 0.05 , namely $0.4>0.05$. The $\mathrm{F}$ count $<\mathrm{F}$ table analysis test shows that $0.733<4.24$ then it is linear. From the results of the analysis test, it shows that the use of the Savi Learning Model and the Science Learning Video Observation Task on the Ability to Think Critically has linearity or relationship between the dependent variable and the independent variable.

\section{Test Analysis T-test}

After testing the linearity between the dependent variable (bound) and the independent variable (free), it is continued by testing the relationship between the dependent variable (bound) and the independent variable (free). Following are the results of the t-test analysis:

T-Test Analysis of Using SAVI Learning Model with the Task of Observation of Science Learning Videos in Producing Analytical Thinking Ability 
Table 8. Results of t-test scores using the SAVI learning model with the task of observing science learning videos in producing analytical thinking skills

\begin{tabular}{|c|c|c|c|c|c|}
\hline \multirow[t]{2}{*}{ Model } & \multicolumn{2}{|c|}{ Unstandardized Coefficients } & Standardized & $\mathrm{t}$ & Sig. \\
\hline & B & Std. Error & $\begin{array}{l}\text { Coefficients } \\
\text { Beta }\end{array}$ & & \\
\hline (Constant) & 68.089 & 6.771 & & 10.057 & 0.000 \\
\hline Analytical Thinking Ability & 0.137 & 0.085 & 0.301 & 1.609 & 0.120 \\
\hline
\end{tabular}

From the table, it explains that there is or does not have an influence relationship between the use of the Savi Learning Model and the Science Learning Video Observation Task on Analytical Thinking Ability where the significant level is $5 \%$ or less than 0.05 , namely $0.120>0.05$. The $\mathrm{t}_{\text {count }}<\mathrm{t}_{\text {table }}$ analysis test shows that 1.609 $<2.056$ means that there is no direct effect. The results of the analysis test indicate that the use of the Savi Learning
Model and the Science Learning Video Observation Task on Analytical Thinking Ability has no direct relationship or a direct relationship between the dependent variable and the independent variable (independent).

T-Test Analysis of Using the SAVI Learning Model with the Task of Observation of Science Learning Videos in Producing Critical Thinking Ability

Table 9. Results of t-test scores using the SAVI learning model with the task of observing science learning videos in producing critical thinking skills

\begin{tabular}{|c|c|c|c|c|c|}
\hline \multirow[t]{2}{*}{ Model } & \multicolumn{2}{|c|}{ Unstandardized Coefficients } & $\begin{array}{l}\text { Standardized } \\
\text { Coefficients }\end{array}$ & $\mathrm{t}$ & Sig. \\
\hline & $\mathrm{B}$ & Std. Error & Beta & & \\
\hline (Constant) & 52.633 & 8.569 & & 6.142 & .000 \\
\hline Critical Thinking Ability & .333 & .108 & .516 & 3.075 & .005 \\
\hline
\end{tabular}

From the table, it explains that there is or does not have an influence relationship between the use of the SAVI learning model and the task of observing science learning videos on critical thinking skills, where the significant level is $5 \%$ or less than 0.05 , namely 0.05 $<0.05$. The $t_{\text {count }}<t_{\text {table }}$ analysis test shows that 3.075> 2.056 then there is a direct effect. From the results of the analysis test shows that the use of the Savi Learning Model and the Science Learning Video Observation Task on Critical Thinking Ability has a direct relationship or direct relationship between the dependent variable and the independent variable (independent). From the results of the analysis by the data obtained:

In measuring the ability to think analytically by using the task of observing instructional video media in the SAVI learning model, it shows that there is no direct influence because there are other factors that affect the inhibition of students' analytical thinking skills. Students' analytical abilities may be still not honed in analyzing a given problem or students have not been trained in expressing analytical thinking skills into an answer. It is proven that there is no direct relationship from the $\mathrm{t}$-test, namely $\mathrm{t}$ count $<\mathrm{t}$ table shows that 1.609 $<2.056$, so there is no direct effect. In measuring the ability to think analytically, preliminary testing is needed in seeing the initial abilities of students or students, in conducting this research the researcher conducted an initial test by making several questions in the form of problems in science education and learning.
At this stage, students do not experience difficulties because they have experienced and are only in the form of opinions with satisfactory results. Then given some discussion of educational problems, especially in science learning and then tested with the task of observing the science learning video here students have difficulty in analyzing science learning in the class where it is possible that students have not felt the class conditions that occur then the class character and students being taught do not know their character only utilize the senses of sight, hearing and feel facial expressions in the video by writing down the findings obtained in the science learning video. So the reason for the occurrence of the SAVI learning model does not have a direct effect there may be several problem factors, namely the discussion to be discussed, the discussion media, and the discussion conditions or discussion difficulties to be tested are possible because the problem is that students do not directly experience the learning so it is rather difficult to analyze the events science learning that is ongoing in the learning video. In the results, these conditions are similar to the results of research by Polina (2020) explaining that the conditions of learning outcomes depend on the learning process, in other words, that success in learning depends on experience in learning.

In measuring the ability to think critically by using the task of observing instructional video media in the SAVI learning model, it shows that there is a direct 
effect because students are invited to give opinions on problems in the form of questions given. So that students' critical thinking skills are honed through direct learning (learning experiences) by activating all their sensory and intellectual abilities. In line with the results of Iskandar's research, Hamdani and Suhartini (2016) explained that the SAVI learning model can produce critical thinking skills, namely through several stages of learning which produces an ability based on minimum standards in stage 3 of learning, namely 83.2 which results in a score in the research sample around 0.89 is higher than the previous learning method. Furthermore, from the conclusions of Sutarna's (2018) research, it can be concluded that the SAVI (somatic auditory-visual intellectual) learning model can affect increasing the ability to ask questions and express opinions, increase students' critical thinking skills and can improve learning outcomes of fourth-grade students of Cimulya State Elementary School.

The results of this study can be explained that the SAVI Learning Model allows improving the ability to think analytically and can improve critical thinking skills, therefore learning that involves a learning process with direct experience involves students to continue to use their thinking and five senses skills (SAVI) to produce expected learning. In line with the research results of Victorina (2019), it is explained that learning using the SAVI learning model will have a large impact on learning outcomes compared to learning with conventional (traditional) methods. Furthermore, the results of this study are also in line with the results of Woschank and Pacher's research (2021) that learning must be holistic in which every learning must be connected between learning and structured theories to produce competitive abilities with the help of technological media.

\section{Conclusion}

From the results of the study, it can be concluded that the Somatic, Audiotorist, Visual and Intelligent (SAVI) learning model can improve and help develop critical thinking skills, while improving and developing analytical thinking skills requires learning stages that emphasize an early or previous learning experience in learning when using the SAVI learning model.

\section{References}

Ariyani, F., Nayana, T., Saregar, A., Yuberti, Y., \& Pricilia, A. (2018). Development of Photonovela with Character Education: As an Alternative of Physics Learning Media. Jurnal Ilmiah Pendidikan $\begin{array}{lll}\text { Fisika Al-Biruni, } & \text { 7(2), 227-237. }\end{array}$ doi:https:// doi.org/10.24042/jipfalbiruni.v7i2.307 $\underline{2}$

Armawati, A., Samad, A., \& Azis, A. (2017). Penerapan Model Pembelajaran SAVI ( Somatic, Auditori, Visual Dan Intelektual ) Dapat Meningkatkan Hasil Belajar Fisika Pada Peserta Didik Kelas VII.A SMP Aisyiyah Sungguminasa. Jurnal Pendidikan Fisika, $3(2), \quad 116 \quad-122$. doi:https://doi.org/10.26618/jpf.v3i2.258

Dewantara, D., Jamal, M.A., \& An'nur, S. (2013). Meningkatkan Hasil Belajar Siswa Kelas XI IPA-1 SMA Negeri 1 Jorong Melalui Pembelajaran Kooperatif Tipe Somatic Auditory Visual And Intellectual Pada Pokok Bahasan Impuls dan Momentum. Berkala Ilmiah Pendidikan Fisika, 1(2), 159-168. doi: http://dx.doi.org/10.20527/bipf.v1i2.873

Fatmawati, H., Mardiyana, M., \& Triyanto, T. (2014). Analisis Berpikir Kritis Siswa dalam Pemecahan Masalah Matematika Berdasarkan Polya Pada Pokok Bahasan Persamaan Kuadrat (Penelitian pada Siswa Kelas X SMK Muhammadiyah 1 Sragen Tahun Pelajaran 2013/2014). Jurnal Pembelajaran Matematika, 2(9). Diambil dari https://jurnal.fkip.uns.ac.id/index.php/s2math/ article/view / 4830

Ginting, S.M., \& Amir, H. (2012). Penerapan Model Pembelajaran Somatis Auditori Visual Dan Intelektual (SAVI) Berbantuan Media Komputer Untuk Meningkatkan Kualitas Pembelajaran Kimia Fisika II. Jurnal Exacta, 10(1), 98-105

Hasnah, Y., \& Dewi, R.S. (2018). Peningkatan Prestasi Belajar Mahasiswa Melalui Pendekatan SAVI Pada Mata Kuliah Curriculum and Material Development. JURNAL TARBIYAH, 25 (2), 132-15. P-ISSN: 08542627, E-ISSN: 2597-4270, doi: http://dx.doi.org/10.30829/tar.v25i2.368

IlmaR., HamdaniA., \& LailiyahS. (2017). Profil Berpikir Analitis Masalah Aljabar Siswa Ditinjau dari Gaya Kognitif Visualizer dan Verbalizer. JRPM (Jurnal Review Pembelajaran Matematika), 2(1), 1-14. https://doi.org/10.15642/jrpm.2017.2.1.1-14

Iskandar, D., Hamdani, A.R., \& Suhartini, T. (2016). Implementation Of Model Savi (Somatic, Audiotory, Visualization, Intellectual) To Increase Critical Thinking Ability In Class Iv Of Social Science Learning On Social Issues In The Local Environment. Journal of Education, Teaching and Learning, $\quad 1(1), \quad 45-50 . \quad$ doi: http://dx.doi.org/10.26737/jetl.v1i1.35.

Kencanawati, S., Sariyasa, S., \& Hartawan, I. (2020). Pengaruh penerapan model pembelajaran SAVI (Somatic, Auditory, Visual, Intellectual) terhadap kemampuan berpikir kreatif matematis. Pythagoras: 
Jurnal Pendidikan Matematika, 15(1), 13-23. doi:https:// doi.org/10.21831/pg.v15i1.33006.

Silvester Mas. (2012). Peningkatan Kemampuan Berpikir Kritis Siswa Kelas V SD Daleng Manggarai Barat NTT Pada Pokok Bahasan Globalisasi Dengan Model Tasc. J-TEQIP, III(1).

Polonia, B.S.E, \& Ravi, A. (2020) Effect of Direct Instruction Models Toward Students' Understanding of Physics Formula. Berkala Ilmiah Pendidikan Fisika. 8(2), doi: 10.20527/bipf.v8i2.8329

Rahmayanti, P.R., Wati, M., \& Mastuang. (2016). Pengembangan Modul Suhu Dan Kalor Menggunakan Model Pembelajaran Kooperatif Tipe Somatic, Auditory, Visual, And Intellegent (SAVI) Untuk Siswa Kelas X SMA Negeri 7 Banjarmasin. Berkala Ilmiah Pendidikan Fisika, 4 (3), 192-200, doi: http://dx.doi.org/10.20527/bipf.v4i3.1301

Septian, A., Ramadhanty, C.L., Rachmawati, P. (2020). Pengaruh Pendekatan Somatis Auditori Visual Intelektual (SAVI) Terhadap Peningkatan Kemampuan Koneksi Matematis Siswa SMA. Journal of Instructional Mathematics, 1(1), 1-10., doi: 10.37640/jim.v1 i1 .253

Sumaryanta. (2018). Penilaian HOTs Dalam Pembelajaran Matematika. Indonesian Digital Journal of Mathematics and Education, 8(8). http://idealmathedu.p4tkmatematika.org.

Sutarna, N. (2018). Pengaruh Model Pembelajaran Savi (Somatic Auditory Visual Intellectualy) Terhadap Hasil Belajar Siswa Kelas IV Sekolah Dasar. JPPD, 5 (2), 119-126.

Undang-Undang No. 20 Tahun 2003, Tentang Sistem Pendidikan Nasional (Sisdiknas).

Victorina, A., \& Ramadhan, S. (2019). The Effects of Using Somatic, Auditory, Visual, Intellectual as Learning Model towards Students Competency Skill in SMPN 1 Koto Baru Dharmasraya. International Journal of Progressive Sciences and Technologies (IJPSAT). 15(2),. http://ijpsat.ijshtjournals.org

Wijayanti, T.F., Prayitno, B.A., \& Marjono. (2013). Pengaruh Pendekatan SAVI Melalui Model Pembelajaran Kooperatif Tipe STAD Terhadap Hasil Belajar Pada Siswa Kelas VII SMP Negeri 14 Surakarta. Pendidikan Biologi, 5 (1), 1-14

Woschanka, M., \& Pacher, C. (2020). A Holistic Didactical Approach for Industrial Logistics Engineering Education in the LOGILAB at the Monta Universitaet Leoben. Procedia Manufacturing 51, 1814-1818. www.sciencedirect.com

Yuliastiono, D., \& Sedyawati, S. (2015). Pembelajaran Somatik Auditori Visual Intelektual (Savi) Dengan Media Compact Disc Interaktif. Jurnal Inovasi Pendidikan Kimia, 7(2). Retrieved from
https://journal.unnes.ac.id/nju/index.php/JIPK/ article/view/4417.

Yuliatun, S., Sukarmin., \& Surantoro. (2018). Remediasi Pembelajaran Fisika Menggunakan Model Somatic, Auditory, Visualization, Intellectualy (SAVI) pada Materi Usaha dan Energi Kelas X SMA Negeri 5 Surakarta. Jurnal Materi dan Pembelajaran Fisika (JMPF) 2 (8), $\quad$ 52-57. doi: https://doi.org/10.20961/jmpf.v8i2.28444 